\title{
Fundraising w kontekście podmiotów ekonomii społecznej
}

\author{
Łukasz Hajduk*
}

Streszczenie: Fundraising to planowe, etyczne i skuteczne zbieranie pieniędzy, które mają służyć dobru wspólnemu. Takim wspólnym dobrem jest niewątpliwie ekonomia społeczna. Dlatego warto zastanowić się nad pozyskiwaniem funduszy na tego typu działalność. Celem artykułu jest zaprezentowanie fundraisingu w kontekście pozyskiwania funduszy na rzecz podmiotów ekonomii społecznej. Autor charakteryzuje polski fundraising z jego historią i rozwojem w ostatnich latach, omawia metodykę pozyskiwania funduszy, ze zwróceniem uwagi na charakterystyczne zasady oraz etykę a także cztery główne źródła pozyskiwania funduszy. Autor tekstu - nauczyciel akademicki a jednocześnie certyfikowany fundraiser - opisuje proces pozyskiwania funduszy bazując na własnych doświadczeniach, uzupełniając je o analizę treści wybranych portali i książek z dziedziny fundraisingu.

Opisany fundraising jest podstawą dla rozwoju i skuteczności podmiotów ekonomii społecznej. Korzystanie przez nie ze wszystkich czterech omówionych źródeł pozyskiwania funduszy jest gwarantem stabilizacji tych podmiotów na rynku. Wartą przemyślenia kwestią wydaje się też być konieczność zatrudnienia fundraisera. Przedsiębiorstwa społeczne mają zbyt wiele do stracenia, aby pozwolić sobie na nieefektywne pozyskiwanie funduszy, dlatego zagadnienia poruszone w tekście powinny znaleźć odzwierciedlenie w rzeczywistości.

Słowa kluczowe: fundraising, ekonomia społeczna, pozyskiwanie funduszu, trzeci sektor, Polskie Stowarzyszenie Fundraisingu.

\section{Wprowadzenie}

Podmioty ekonomii społecznej - zwane w dalszej części artykułu PES - to organizacje łączące w sobie cele społeczne i gospodarze. Jako takie, stanowiąc rdzeń ekonomii społecznej, nazywanej również przedsiębiorczością społeczną, umiejscowione są na styku dwóch, a czasami nawet trzech sektorów. Mamy więc do czynienia z podmiotami sektora pozarządowego lub partnerstwami pomiędzy sektorem publicznym a pozarządowym prowadzącymi ciągłą działalność gospodarczą, co czyni je również podmiotami gospodarczymi. Takie umiejscowienie powoduje, że mechanizmy finansowania PES to, z jednej strony, charakterystyczne dla przedsiębiorstw finansowanie zwrotne (pożyczki, kredyty, obligacje), z drugiej finansowanie bezzwrotne (granty, dota- cje, subwencje, darowizny) związane z sektorem non profit [Królikowska, 2008, s. 39] Przy czym nacisk położony jest na działalność gospodarczą, która powinna stanowić główne źródło dochodu. Takie podejście w znacznej mierze ułatwić może rozwój i funkcjonowanie podmiotów ekonomii społecznej. Jednocześnie, badacze tematu wskazują, że dostęp do źródeł finansowania PES jest wciąż jednym z poważniejszych ograniczeń w ich rozwoju [Pełka, 2012, s. 41]. Dlatego równolegle z rozwojem ekonomii społecznej w Polsce prowadzone są ciągłe dyskusje na temat możliwości jej efektywnego finansowania, pozwalającego na utrzymanie się

\footnotetext{
* Łukasz Hajduk Instytut Pedagogiki Uniwersytetu Jagiellońskiego ul. Batorego 12, 31-135 Kraków e-mail: lukasz.hajduk@uj.edu.pl
} 
na rynku. Spory wkład do tej dyskusji wniósł, realizowany $\mathrm{w}$ ramach Inicjatywy Wspólnotowej EQUAL w latach 2005-2008, projekt W poszukiwaniu polskiego modelu ekonomii społecznej'. Jednym z efektów projektu są liczne artykuły dotyczące finansowania PES [Herbst, 2008; Królikowska, 2008; Głowacki, 2008; Hausner (red.), 2008; Płonka 2008; Karwińska, Sułkowska, 2008]. Również późniejsze projekty dotyczące rozwoju i promocji ekonomii społecznej ${ }^{2}$ owocowały opracowaniami na temat finansowania [Sobolewski i inni, 2009; Cibor, 2015; Głowacki, Sułkowski, 2012]. Jednak problematyka fundraisingu nie została tam szczegółowo opisana. Wyjątek stanowi publikacja wydana w ramach programu edukacji ekonomicznej, gdzie zagadnienie fundraisingu w ekonomii społecznej rozwija prezes Polskiego Stowarzyszenia Fundraisngu - Jerzy Mika [Mika, 2015]. Dlatego w niniejszym artykule omówione zostaną treści związane z pozyskiwaniem funduszy w PES, opartym na założeniach fundraisingu. Celem artykułu jest charakterystyka fundraisingu, jego zasad, metodyki, źródeł finansowania, ze szczególnym zwróceniem uwagi na elementy istotne dla ekonomii społecznej. Jak już zostało wskazane, jest to podejście słabo eksplorowane w ekonomii społecznej, choć zauważane zarówno przez praktyków, czego przykładem są odbywające się szkolenia fundraisingowe dla przedstawicieli PES [Głowacki, 2008, s. 56], jak i badaczy dzielących się swoimi spostrzeżeniami w niektórych publikacjach [Mazur, Pacut, 2008, s. 64; Mika, 2015]. Fundraising, jako proces pozyskiwania funduszy nadal jednak częściej kojarzony jest z trzecim sektorem o charakterze non profit (zwłaszcza z działalnością fundacji i stowarzyszeń), niż z podmiotami

\footnotetext{
http://es.ekonomiaspoleczna.pl/, dostęp 28.06.2016.

Np. INES - Infrastruktura Ekonomii Społecznej w Małopolsce; System wzmacniania potencjału i kompetencji sektora spółdzielczości socjalnej oraz stworzenie sieci współpracy z instytucjami rynku pracy oraz pomocy i integracji społecznej; Zintegrowany System Wsparcia Ekonomii Społecznej.
}

ekonomii społecznej, które prowadząc działalność gospodarczą nastawione są na zysk. Upowszechnianie wiedzy na temat fundraisingu jest potrzebne, gdyż jeszcze do niedawna miała ona charakter intuicyjny i była poruszana jedynie w anglojęzycznych opracowaniach [Grzegorczyk, 2009, s. 3].

$\mathrm{Na}$ początku tekstu, po zdefiniowaniu podstawowych pojęć i odniesieniu się do kwestii prawnych, podana jest charakterystyka fundraisingu z jego polską historią i rozwojem w ostatnich latach. Dalsza część dotyczy sposobów pozyskiwania funduszy, ze zwróceniem uwagi na kluczowe zasady fundraisingu oraz etykę. Istotną częścią jest charakterystyka czterech głównych źródeł pozyskiwania funduszy, ze szczególnym zwróceniem uwagi na przydatność tych źródeł w ekonomii społecznej. W podsumowaniu przedstawiona jest specyfika PES, która może być szansą, ale również zagrożeniem dla działań fundraisingowych.

\section{Podstawowe pojęcia}

Aby nadać wywodowi spójne podłoże, warto na początku zdefiniować podstawowe pojęcia oraz odnieść się porządkujących całość kwestii prawnych. Jest to szczególnie istotne biorąc pod uwagę chaos definicyjny panujący w dziedzinie ekonomii społecznej [Giza-Poleszczuk (red.), 2008, s. 36]. Ekonomię społeczną, określaną również jako gospodarka społeczna lub przedsiębiorczość społeczna rozumiem jako jeden ze sposobów określenia działalności gospodarczej, który łączy w sobie cele społeczne i ekonomiczne [FISE]. Natomiast przez podmioty ekonomii społecznej, inaczej nazywane przedsiębiorstwami społecznymi, rozumiem podmioty prowadzące działalność o celach głównie społecznych, z której zyski w założeniu są reinwestowane $w$ te cele lub we wspólnotę. Dochody w takich podmiotach nie są wykorzystywane w celu maksymalizacji zysku, zwiększenia dochodu udziałowców czy też 
właścicieli tych podmiotów. Jest to podejście zaproponowane przez European Research Network [FISE]. Zgodnie z nim, PES powinny spełniać większość z podanych poniżej kryteriów ekonomicznych i społecznych.

Kryteria ekonomiczne:

- prowadzenie w sposób względnie ciągły, regularny działalności w oparciu o instrumenty ekonomiczne,

- niezależność, suwerenność instytucji w stosunku do instytucji publicznych,

- ponoszenie ryzyka ekonomicznego,

- istnienie choćby nielicznego płatnego personelu.

Kryteria społeczne:

- wyraźna orientacja na społecznie użyteczny cel przedsięwzięcia,

- oddolny, obywatelski charakter inicjatywy,

- specyficzny, możliwie demokratyczny system zarządzania,

- możliwie wspólnotowy charakter działania,

- ograniczona dystrybucja zysków.

Ponieważ PES umiejscowione są na styku drugiego i trzeciego sektora, często przy partnerskim udziale administracji publicznej, zdefiniuję również te pojęcia. Odnoszą się one do podziału aktywności społeczno-gospodarczej nowoczesnych państw demokratycznych na trzy sektory zaproponowanego przez amerykańskiego socjologa Amitaia Etzioniego. Według tej typologii pierwszy sektor to administracja publiczna (sektor państwowy), drugi to sfera biznesu, nazywana też sektorem prywatnym (instytucje i organizacje, których działalność jest nastawiona na zysk), wreszcie trzeci to organizacje pozarządowe, działające społecznie i nie dla zysku. [DESiPP]. W wymiarze prawnym funkcjonowanie podmiotów opisywanych w tekście regulują m.in. ustawy: o działalności pożytku publicznego i wolontariacie z 2003 r., o fundacjach z 1984 roku, o spółdzielniach socjalnych z 2006 r. oraz prawo o stowarzyszeniach z 1989 r.

\section{Historia i stan obecny fundraisungu w Polsce}

Fundraising to anglojęzyczny termin połączenie słów: „fund” (fundusze) oraz „raising" (pozyskiwać, zbierać, gromadzić) - który na dobre zagościł już w polskiej nomenklaturze. Określa się nim proces pozyskiwania funduszy na działalność społeczną i charytatywną. Tym samym fundraiser to osoba zajmująca się pozyskiwaniem funduszy. Organizacje związane z fundraisingiem rozszerzają tę definicję mówiąc o planowym, regularnym, etycznym i skutecznym zbieraniu pieniędzy, które mają służyć dobru wspólnemu [Instytut Fundraisingu b; Polskie Stowarzyszenie Fundraisingu]. Jednak istotą tego procesu są nie tylko pieniądze, ale także wieloletnie, stabilne relacje - zarówno z darczyńcami, jak i z beneficjentami oraz członkami organizacji pozarządowych. Podkreśla się również, że fundraising to zagadnienie z dziedziny zarządzania organizacjami i gospodarowania finansami, związane z odpowiednią metodyką oraz etyką. Nieco inaczej definiuje fundraising Adam Grzegorczyk, który wskazuje na jego ścisłe połączenie ze wspomnianą filantropią. „Fundraising jest formułą organizacyjną dobroczynności, przy czym nie jedyną i nie najbardziej powszechną. Jednocześnie trzeba zauważyć, że idea fundraisingu nie miałaby jakichkolwiek podstaw istnienia, gdyby nie równoległa idea filantropii (...), rozumiana jako działalność osób bądź instytucji, polegająca na bezinteresownym udzielaniu pomocy finansowej lub materialnej potrzebującym" [Grzegorczyk, 2009, s. 134]. W tym kontekście istotą omawianego procesu staje się dobroczynność, a zadaniem fundraisera pozyskanie odpowiedniej pomocy i przekazanie jej do właściwego odbiorcy. Zaprezentowane definicje uzupełniają się wzajemnie, co powoduje, że proces fundraisingu oprócz ekonomicznego nabiera także społecznego 
charakteru i staje się czymś więcej niż tylko filantropią.

Pozyskiwanie funduszy na działalnośćspołeczną i charytatywną ma swoje bogate tradycje ściśle powiązane z rozwojem wspomnianej już filantropii. W średniowieczu [Frączak, 2006] praktykowana były jałmużna i fundacje, które stanowiły sposób realizacji - prowadzącej do zbawienia - idei miłosierdzia. Przykładem są zakony żebracze, których działalność całkowicie opierała się na pozyskanych funduszach. Taka forma życia zakonnego w Polsce przeżywała swój największy rozkwit w XIV i XV wieku. Innym przykładem omawianych praktyk, dominującym w naszym kraju do XVIII wieku były, poza zakonami, także szpitale. Na przestrzeni stuleci wykształciło się w Polsce wiele innych podmiotów o charakterze społecznym czy charytatywnym, których funkcjonowanie możliwe było tylko dzięki finansowemu wsparciu bogatszych warstw społeczeństwa. Rozwój filantropii, działalności charytatywnej, a także idei ekonomii społecznej swoje apogeum osiągnął na przełomie XIX i XX wieku oraz później w okresie 20-lecia międzywojennego. Dopiero czasy PRL zahamowały liczne dobre praktyki do tego stopnia, że po 1989 r. zapomniano o wielu z nich. Wspomina o tym Jerzy Mika: „Idea filantropii jest obecna na całym świecie. Polskie społeczeństwo jest jednak po wielu latach formalnego i ideologicznego zniewolenia mało charytatywne na tle społeczeństw świata" [Mika (red.), 2014, s. 11]. W tym kontekście, zapoczątkowany dopiero $\mathrm{w} X X \mathrm{XI}$ wieku fundraising bardzo mocno bazuje na bogatej polskiej tradycji. Jednak bezpośrednie źródło fundraisingu ma swoje miejsce na kontynencie amerykańskim.

Robert Kawałko - inicjator powstania Polskiego Stowarzyszenia Fundraisingu - tak wspomina jego historię. „Był początek 2005 r., gdy odwiedzając Martę Foryś w jej biurze na Akademii Górniczo-Hutniczej wspomniałem jej o I Kongresie Fundraisingu w Mexico City, który miał się odbyć w lutym. Półżartem powiedziałem wtedy: »Dobrze byłoby tam pojechać, bo na pewno będzie ciekawie«. Marta - do dziś nie wiem dlaczego - wzięła to jednak na poważnie i po kilku dniach zadzwoniła: »Przekonałam rektora i mam już bilet. A Ty?« Nie będę tu opisywał, ile trudu włożyłem w to, żeby po kilku dniach powiedzieć: »Ja też«. (...) I tak doszło w Meksyku do spotkania, które miało zmienić tak wiele! Po raz pierwszy Polacy rozmawiali o fundraisingu z najważniejszymi postaciami tej profesji z USA, Wielkiej Brytanii i innych krajów. Już wtedy, zafascynowani tym, co zobaczyliśmy i usłyszeliśmy na meksykańskim kongresie, złożyliśmy im obietnicę, że niebawem powstanie nasza własna narodowa organizacja, która zbuduje w Polsce fundraising. 28 stycznia 2006 r. ta obietnica została spełniona, choć wielu mówiło wtedy, że ta inicjatywa jest co najmniej o 5 lat za wczesna. Tego dnia w Warszawie przy Chmielnej 15 spotkało się 18 założycieli Polskiego Stowarzyszenia Fundraisingu (PSF). W większości byli to przedstawiciele zaproszeni spośród organizacji nagrodzonych w konkursie Pro Publico Bono. (...) Dosłownie kwadrans po walnym zebraniu już dzwoniliśmy do drzwi Ambasady Stanów Zjednoczonych. W końcu to od Amerykanów zaraziliśmy się wirusem fundraisingu, więc wracamy do epicentrum" [Mika (red.), 2014, s. 17-18]. Amerykanie przyznali fundusze, za które PSF wiosną 2007 r. zorganizowało pierwszą w Polsce konferencję fundraisingową. Od samego początku PSF jest członkiem Europejskiego Stowarzyszenia Fundraisingu (EFA). Kolejne etapy rozwoju to szkolenia dla trenerów pozyskiwania funduszy, a następnie certyfikowane szkolenia dla fundraiserów. Do końca 2014 r. zostało przeszkolonych 8000 osób. Wśród nich jest 300 absolwentów Certified Fund Raiser (CFR), najważniejszego szkolenia realizowanego przez PSF, opartego na europejskich standardach kształcenia zawodowego fundraiserów. PSF jako jedyny w Polsce ma prawo przyznawania absolwentom kursu sygnowanego przez EFA certyfikatu, który potwierdza profesjo- 
nalne kwalifikacje i jest uznawany na całym świecie. Poza szkoleniami i kursami rokrocznie są organizowane dwudniowe, międzynarodowe konferencje. W 2015 r., w Warszawie, odbyła się 9 edycja konferencji. Ponadto PSF regularnie organizuje spotkania Klubu Fundraiserów, prowadzi konsultacje eksperckie z zakresu kampanii fundraisingowych oraz wprowadzania strategii fundraisingowej do organizacji. PSF angażuje się w tworzenie odpowiedniego środowiska prawnego dla fundraiserów i organizacji pozarządowych, a także dba o budowanie sieci zawodowych fundraiserów. Stowarzyszenie jest aktywne w przestrzeni europejskiej. Istotą PSF jest dbałość o rozwój etycznego i w pełni profesjonalnego pozyskiwania funduszy na działalność społeczną i charytatywną. „[...] W wizji PSF na przyszłość każda organizacja i instytucja społeczna ma zatrudniać przynajmniej jednego zawodowego fundraisera. Tak samo, jak zatrudniają księgowych. Do tego celu droga jeszcze daleka, ale każdy datek pozyskany zgodnie z planem, wydany zgodnie z celem i rozliczony zgodnie z przepisami przybliża nas do Polski, w której kwitnie kultura filantropii. Gdzie nikt nie jest zaniedbany ani zapomniany, bo każdy potrzebujący ma swojego ambasadora, który w jego imieniu rozmawia z darczyńcami, poszukuje dla niego pomocy. Tymi ambasadorami są właśnie fundraiserzy!" [ibidem, s. 21].

\section{Kluczowe zasady fundrasingu}

Nie ma wątpliwości, że to PSF zapoczątkowało nowa erę fundraisingu w Polsce. Tym samym PSF dba o jakość wszelkich procesów, kryjących się pod tym hasłem. Na pierwszym miejscu jest zatem budowanie relacji, pozyskiwanie nowych kontaktów, tworzenie sieci, w których swoje miejsce mają zarówno darczyńcy, jak i fundraiserzy, członkowie organizacji pozarządowych oraz beneficjenci. A ponieważ fundraising to idea, które ma zmieniać świat, to założenia, na których się opiera też są wielkie. Stąd cztery podstawowe zasady fundraisingu, przez samych fundraiserów nazywane „wielkimi”: kultywowanie, twórczość, charytatywność, przejrzystość.

Zasada kultywowania bezpośrednio odnosi się do budowania relacji. Według słownika „kultywować" to utrzymywać i rozwijać jakieś tradycje, zwyczaje, wartości [PWN]. To fundraiser jest odpowiedzialny za rozwijanie tradycji przekazywania datków na cele społeczne i charytatywne. Fundraiser przedstawia potencjalnym darczyńcom zaangażowanie w zbiórkę jako wartość. Również fundraiser, odpowiednio traktując darczyńców, dziękując im, utrzymując z nimi kontakt, buduje relacje, które przynoszą to, co w fundraisingu ma szczególne znaczenie - stałych, regularnych darczyńców. Aby pozyskiwać stałych darczyńców, którzy w regularny sposób będą wspierać dane dzieła, potrzeba Wielkiego Celu oraz odpowiednich narzędzi, które pomogą ten cel komunikować innym. Tutaj z pomocą przychodzi druga zasada - twórczości. Dzięki niej fundraiserzy nie czują się ograniczeni daną liczbą technik pozyskiwania funduszy. Sami bądź przekształcają, bądź tworzą nowe techniki i narzędzia. Każda kampania fundraisingowa to swoistego rodzaju dzieło sztuki. Nie bez powodu fundraiserzy, parafrazując tłumaczenie swojej profesji, mówią nie o FUNDraisingu tylko o FUNraisingu - czyli o pozyskiwaniu zabawy, uciechy. Aby jednak nie przekroczyć pewnych granic mamy trzecią zasadę - dobroczynności, charytatywności. Przypomina ona o tym, że wszystko co wiąże się z fundraisingiem - pozyskiwanie funduszy, budowanie relacji, filantropia - jest związane z działalnością charytatywną bądź społeczną. Dodatkowym zabezpieczeniem przez wszelkimi nadużyciami jest czwarta zasada - przejrzystości. Mówi ona o tym, że każda złotówka pozyskana przez fundraisera jest uczciwie rozliczana, a informacje na temat rozliczenia są przekazywane opinii publicznej. Dlatego powszechnym zwyczajem jest informowanie o wyni- 
kach kampanii fundraisingowych za pomocą różnorodnych mediów. Każdy darczyńca powinien wiedzieć, co dzieje się z jego pieniędzmi. W tym kontekście ujawniane powinny być również koszty administracyjne oraz inne koszty kampanii czy funkcjonowania organizacji. Te cztery przytoczone zasady pozwalają utrzymać wysoki poziom fundrasingu w Polsce a tym samym wysoki poziom całego trzeciego sektora - w tym również podmiotów ekonomii społecznej.

Spoiwem dla przedstawionych zasad jest etyka, która jest bardzo istotna w metodyce pozyskiwania funduszy, o czym świadczy wypracowanie odrębnych dokumentów - deklaracji etycznych. Pierwszym z nich jest Międzynarodowa Deklaracja Zasad Etycznych w Fundraisingu. Dokument ten został uchwalony 16 października 2006 r. przez przedstawicieli organizacji fundraisingowych z 24 państw podczas IV Międzynarodowego Szczytu Fundraisingu w Noordwijkerhout (Holandia). PSF brał udział w końcowych opracowaniach deklaracji, a po jej ogłoszeniu na forum międzynarodowym, wprowadził ją w Polsce. Drugim dokumentem jest nasza rodzima deklaracja - Deklaracja Etyczna Fundraisingu z 14 października 2011 r. Ogłoszona została podczas konferencji fundraisingu w Warszawie. Już sama preambuła deklaracji stawia polskiemu fundraisingowi wysokie wymagania etyczne. „Motywowani pragnieniem służby ideałom filantropii, poświęceniu na rzecz obrony godności ludzkiej i dbania o dobro wspólne przy zachowaniu różnorodności kulturalnej i pluralizmu oraz świadomi spoczywającej na nas moralnej odpowiedzialności wynikającej z pozyskiwania środków na działalność społeczną, pragnąc zdefiniować wartości, pomagające pogłębić transparentność, chronić prywatność i godność podopiecznych, a także zdobyć zaufanie społeczne i sprostać oczekiwaniom darczyńców, szanując ich prywatność, niezależność i interesy my, niżej podpisani, niniejszym przyjmujemy Deklarację Etyczną Fundraisin- gui zobowiązujemy się do przestrzegania jej zasad" [Mika (red.), 2014, s. 263]. Zasady etyczne wynikające z obu deklaracji to: uczciwość, szacunek, konsekwencja, empatia i przejrzystość. Ponadto uregulowane zostały kwestie związane z odpowiedzialnością fundraiserów, relacjami z darczyńcami, raportowaniem działalności, zgodnością działań z prawem narodowym. Ważnym zapisem jest zasada, zgodnie z którą fundraiserzy powinni pracować jako wolontariusze lub za wcześniej ustaloną pensję. Niezgodnym z zasadami etyki jest pobieranie prowizji opartej na obliczaniu procentu od pozyskanej kwoty. Przyjęte zasady etyczne są gwarantem, że wszystkie aspekty pozyskiwania funduszy są realizowane na najwyższym poziomie.

\section{4. Źródła pozyskiwania funduszy w ramach fundrasingu}

Po zwróceniu uwagi na etykę można przejść do kluczowego zagadnienia w fundraisingu, jakim są źródła pozyskiwania funduszy. Określa się cztery podstawowe: działalność gospodarcza, granty, darczyńcy indywidualni oraz sponsoring. Biorąc pod uwagę PES, każe z tych źródeł ma nieco inne znaczenie. Warto więc przyjrzeć się każdemu z nich. Podane źródła korelują z najczęściej przytaczanym w literaturze przedmiotu podziałem na finansowanie podmiotów ekonomii społecznej: własne (działalność gospodarcza), publiczne (granty) i prywatne (darczyńcy indywidualni, sponsorzy) ${ }^{3}$ [Pełka, 2012, s. 43].

Działalność gospodarcza jest tym źródłem, które wyróżnia PES z szeroko pojmowanego trzeciego sektora. Organizacja pozarządowa - szczególnie dotyczy to fundacji i stowarzyszeń - która rejestruje działalność gospodarczą, tym samym staje się podmiotem ekonomii społecznej. Jednym z ekono-

Czwartym rodzajem jest finansowanie przez instrumenty dłużne, taki jak fundusze pożyczkowe, fundusze poręczeniowe, to źródło nie ma odzwierciedlenia w fundraisingu. 
micznych kryteriów przedsiębiorczości społecznej jest właśnie prowadzenie w sposób ciągły i regularny działalności gospodarczej, czyli takiej, która przynosi dochód, zarobek. Warto nadmienić, że działalność gospodarcza może być prowadzona przez samą organizację lub przez powołaną do tego celu spółkę. W Polsce przedmiotem działalności gospodarczej organizacji pozarządowych najczęściej są działalności: edukacyjna i szkoleniowa, turystyczna i gastronomiczna, wydawnicza i poligraficzna oraz handlowa. W przypadku PES właśnie działalność gospodarcza powinna być tym najistotniejszym źródłem funduszy pozwalających na realizację przyjętych celów i jednocześnie budującym tożsamość tego typu podmiotów. Pomysły na działalność gospodarczą - znalezienie niszy na rynku, konkurencyjna oferta, profesjonalny produkt lub usługa - są warunkiem sukcesu lub porażki dla danej organizacji. Od pomysłu i sposobu jego realizacji zależy przecież powodzenie misji społecznej, która obok działalności gospodarczej jest drugim wyznaczniki ekonomii społecznej. Jednak należy pamiętać, że PES - mimo prowadzenia działalności gospodarczej - to wciąż podmioty trzeciego sektora. A jako takie, mają do dyspozycji jeszcze inne źródła finansowania. Jest to istotne $z$ dwóch powodów. Na starcie dodatkowe źródła finansowania mogą zasilić kapitał początkowy, niezbędny do rozpoczęcia działalności gospodarczej. Kiedy działalność gospodarcza zacznie przynosić zyski, dodatkowe źródła dochodów stają się istotnym uzupełnieniem budżetu - zwłaszcza w różnych sytuacjach kryzysowych.

Jednym z tych źródeł są granty, definiowane jako „wsparcie finansowe lub pozafinansowe, przyznawane na realizację określonego celu lub projektu" [Instytut Fundraisingu a]. Dotacje grantowe przyznawane są przez różne podmioty. Najpopularniejszym z nich jest Unia Europejska. Transza na lata 2014 -2020, przyznana przez UE dla Polski wynosi 120,1 miliarda euro [MliR, 2015]. Suma ta roz- kłada się pomiędzy politykę spójności $(82,5$ mld euro), Wspólną Politykę Rolną (32,1 mld euro), Europejski Fundusz Morski i Rybacki (0,5 mld euro) oraz programy takie jak Erasmus czy Horyzont 2020 (5 mld euro). Pieniędzmi zarządzają m.in. Ministerstwo Rozwoju, Ministerstwo Rolnictwa i Rozwoju Wsi oraz zarządy województw. Granty unijne to jednak nie wszystko. Fundusze dla trzeciego sektora - w tym także dla PES - przyznają również jednostki administracji publicznej, samorządy lokalne, firmy, fundacje. Droga do otrzymania dotacji jest podobna, niezależnie od rodzaju grantu. W pierwszej kolejności grantodawca ogłasza konkurs, określając dokładnie jego zasady (m.in. jakie podmioty mogą starać się o fundusze, na jaki cel mogą zostać przeznaczone pieniądze, jakie są koszty kwalifikowane i niekwalifikowane ${ }^{4}$, jaka jest wielkość wkładu własnego ${ }^{5}$ ). Podmioty, które kwalifikują się do udziału w konkursie mogą w wyznaczonym terminie aplikować o środki. W tym celu organizacje opracowują projekty, coraz częściej bazując na dostępnych w sieci Internet formularzach. W końcowej fazie komisja wyznaczona przez grantodawcę ocenia wnioski (ocena formalna i merytoryczna), wyłaniając te najlepsze, które otrzymają grant. Po podpisaniu umowy organizacja (grantobiorca) realizuje zaplanowany projekt, rozliczając go zgodnie z wymaganiami grantodawcy. To długa droga. Często od złożenia wniosku w konkursie, do momentu przekazania funduszy na konto organizacji mija kilka miesięcy. Dotacja może też mieć formę refundacji. Co oznacza, że zostanie przekazana dopiero po zakończeniu projektu i jego prawidłowym rozliczeniu. Dla każdej organizacji to duże ryzyko. Z tematem grantów

\footnotetext{
Koszty kwalifikowane - koszty podlegające refundacji lub dotacji, koszty niekwalifikowane - koszty, które nie mogą podlegać refundacji ani dotacji.

Nieliczne konkursy grantowe zakładają finansowanie całego projektu, w większości przypadków dotacja lub refundacja obejmuje tylko część wydatków, pozostała część finansowana ze środków własnych to tzw. wkład własny.
} 
związane są też inne zagrożenia. W mediach na stałe zagościło już pojęcie "grantozy" - „Ta choroba nie dotyczy człowieka, a systemu przyznawania dofinansowań - głównie z Unii Europejskiej" [Bajguza, 2012]. Media zwracają uwagę na różne oblicza tej choroby. Jednym z nich jest powstawanie organizacji pozarządowych nastawionych tylko na zdobywanie grantów. Celem nadrzędnym takich podmiotów jest pozyskiwanie jak największej ilości dotacji. „To choroba sytemu finansowania publicznego, prowokująca mnożenie się fundacji i stowarzyszeń, które w swoim statucie wpisane mają niemal wszystko - od organizowania festiwali artystycznych, imprez sportowych, po warsztaty zwijania sushi. Organizacje te, wkomponowując się w założenia różnorakich programów grantowych, opanowują do perfekcji sztukę pisania wniosków i wygrywają konkursy" [Lewandowska, 2015]. Innym obliczem "grantozy" są absurdy związane z formalną oceną wniosków. "Granty więc nierzadko wygrywają nie ci najlepsi, ale ci, którzy najlepiej opanowali język projektów unijnych. »Na poziomie centralnym przy podziale środków często działa mechanizm loteryjny, na poziomie lokalnym - koteryjny« - diagnozuje Kuba Wygnański, jeden z czołowych animatorów sektora pozarządowego" [Socha, 2015]. „Grantoza” to często także uzależnienie od projektów. Uzależnione organizacje posiadają tylko jedno źródło finansowania - granty. Takie organizacje funkcjonują tak długo, dopóki otrzymują dotacje grantowe. Kiedy z jakiegoś powodu skończą się dotacje, organizacje upadają. Negatywny wpływ grantów wyraża się głównie w czterech aspektach [Socha, 2015]. Tworzą się podziały na duże, zamożne organizacje, które stać na zatrudnienie specjalistów od pozyskiwania grantów oraz na małe, lokalne, które często nie są w stanie przedostać się na szczyty list rankingowych, decydujących o uzyskaniu finansowania. Po drugie, myślenie o misji społecznej zostaje zastąpione zbiurokratyzowanym myśleniem o projekcie. Jest to zagro- żenie szczególnie istotne w przypadku PES. Kolejny aspekt wiąże się z utratą tożsamości - jest to konsekwencja dopasowywania swojej działalności do wytycznych grantodawcy. Wreszcie ostatnim aspektem jest uzyskiwanie niewielkich korzyści, mimo dużych budżetów w projektach. Wynika to m.in. ze specyfiki kosztów kwalifikowanych oraz znacznych wydatków na zarządzanie projektem. Podsumowując zagrożenia wynikające z grantów, warto podkreślić, że "(...) finansowanie ze środków publicznych psuje przedsiębiorczość społeczną, wykorzystywanie środków publicznych może być przydatne w zainicjowaniu przedsiębiorczości, aby dać pierwszy impuls i początkowe wsparcie rodzącej się inicjatywie społecznej, w późniejszym dojrzałym działaniu, gdy przedsięwzięcie dojrzeje, rozkwitnie i - jak J. Hausner to ujął - zakorzeni się w danej społeczności, trzeba dać jej szanse samodzielnego bytu" [Karwińska, Sułkowska, 2008, s. 10]. Dotacje grantowe mają jednak też dobre strony. W kontekście PES są to przede wszystkim fundusze celowe, skierowane właśnie na rozwój ekonomii społecznej, zwłaszcza - jak zostało zauważone w powyższym cytacie - w fazie startu. Przykładem są środki dostępne dla podmiotów ekonomii społecznej - np. z Funduszu Pracy czy Państwowego Funduszu Rehabilitacji Osób Niepełnosprawnych - czy środki z Europejskiego Funduszu Społecznego. Historie wielu prężnie funkcjonujących PES rozpoczynają się od pozyskania grantu. Przykładem jest dobrze znane, krakowskie "U Pana Cogito"6. Znaczenie grantów podkreślają też sami specjaliści w dziedzinie ekonomii społecznej: „Granty i dotacje stanowią obecnie największą grupę źródeł finansowania. (...) W programach operacyjnych na szczeblu krajowym istnieje szereg działań adresowanych wyłącznie do sektora ekonomii społecznej oraz ujmowanego szerzej trzeciego sektora" [Głowacki, Suł-

\footnotetext{
http://www.stowarzyszenie-rozwoju.eu/programy,100 (dostęp 21.06.2016).
} 
kowski, 2012, s. 87-88]. Granty - czyli środki publiczne - są też najczęściej wybieranym źródłem finansowania PES w Europie [Mazur, Pacut, 2008, s. 72].

Inaczej wygląda pozyskiwanie funduszy z kolejnego źródła, którym są darczyńcy indywidualni. To chyba najważniejsze - po działalności gospodarczej - źródło dla fundraiserów. To tutaj można mówić o stałych, regularnych darczyńcach. Również tutaj fundraiserzy mają do dyspozycji całą gamę różnorodnych technik pozyskiwania funduszy. Istotne jest $\mathrm{w}$ tym przypadku przekonanie darczyńcy, że jego darowizna pozwoli zrealizować szczytny cel, dla którego został powołany dany podmiot. Każdy PES posiada taki cel, sztuką jest jednak tak o nim opowiadać, aby stał się jednocześnie celem słuchaczy, zamieniając ich w darczyńców. Wspólnym mianownikiem wszystkich technik stosowanych w fundraisingu w odniesieniu do indywidualnych osób jest darowizna, którą darczyńca przeznacza na cele statutowe danego podmiotu. Do tej darowizny można jednak doprowadzić na różne sposoby, stosują różne techniku. Może to być datek wrzucony do skarbony: stacjonarnej, umiejscowionej w atrakcyjnym miejscu publicznym, lub ruchomej, podczas kwesty ulicznej. Może to być wpłata za pomocą przelewu bankowego lub z wykorzystaniem narzędzi internetowych. Do wpłaty fundraiser może zachęcać za pomocą listów wysyłanych tradycyjną pocztą lub poprzez pocztę elektroniczną, telefonując lub zachęcając do wpłat face to face na ulicy. Pozyskane fundusze mogą być efektem aukcji, loterii fantowej, wpłat za pomocą sms-ów lub coraz popularniejszej techniki pay roll, która polega na automatycznym potrącaniu, za zgodą pracownika, określonej kwoty z jego miesięcznych poborów. W Polsce coraz więcej organizacji korzysta z tego narzędzia. Mniej popularną w Polsce techniką są spadki przeznaczane na rzecz trzeciego sektora. W Stanach Zjednoczonych czy Wielkiej Brytanii wolontariusze z sukcesem przekonują do takich zapisów. W naszym kraju to narzędzie jest wciąż rzadko stosowane, podobnie jak pozyskiwanie praw autorskich, z których tantiemy czerpie organizacja pozarządowa. Coraz częściej natomiast Polacy oddają organizacjom pożytku publicznego swój 1\% z podatku dochodowego - za 2014 r. było to 557,6 mln złotych [Setniewska, 2015]. Uzupełnieniem przytoczonych technik są różnorodne narzędzia, które pomagają pozyskać darowiznę, jednocześnie czyniąc formę jej pozyskiwania bardziej atrakcyjną. Takim narzędziem są np. kody QR, które mogą stanowić oryginalny element $w$ kampaniach fundraisingowych oraz aplikacje dla użytkowników smartfonów. Osobną uwagę należy zwrócić na składki członkowski. W tym przypadku regularnymi darczyńcami stają się sami członkowie organizacji. Taka forma pozyskiwania funduszy dotyczy tylko podmiotów związanych z członkostwem. Dobrym rozwiązaniem jest też barter, czyli pozyskiwanie towarów i usług zamiast funduszy. Organizacja pozyskane towary - np. sprzęt komputerowy lub samochód - może wykorzystywać do realizacji celów statutowych lub sprzedać. Darczyńcy indywidualni jako źródło funduszy mogą przynieść organizacji również inne korzyści. W ramach wolontariatu mogą ofiarować swój czas i umiejętności. Sami też - po przekonaniu się do celów organizacji - mogą zacząć pozyskiwać fundusze na jej rzecz wśród swoich znajomych. Wszystkie techniki i narzędzia dotyczące darczyńców indywidualnych są korzystnym uzupełnieniem dla działalności gospodarczej prowadzonej przez PES. Klient korzystający z usług danego podmiotu może wspierać wybrane przez siebie cele społeczne nie tylko płacąc za usługę, ale także przekazując darowiznę np. za pomocą 1\% czy wsparcia podczas kwesty. Korzystanie ze wsparcia darczyńców indywidualnych w przypadku PES nie musi się wiązać z utratą charakteru podmiotów gospodarczych, o ile działalność gospodarcza pozostanie głównym, a wsparcie darczyńców dodatkowym źródłem funduszy. Metodą bazującą na darczyńcach indywidual- 
nych jest też tzw. crowdfunding - finansowanie społecznościowe, które na dobre przyjęło się już w naszym kraju. Jednym z głównych propagatorów tej idei w Polsce jest Karol Król, który definiuje crowdfunding jako „rodzaj gromadzenia i alokacji kapitału przekazywanego na rzecz rozwoju określonego przedsięwzięcia w zamian za określone świadczenie zwrotne, który angażuje szerokie grono kapitałodawców, charakteryzuje się wykorzystaniem technologii teleinformatycznych oraz niższą barierą wejścia i lepszymi warunkami transakcyjnymi, niż ogólnodostępne na rynku" [Król, 2013, s. 23]. Crowdfunding to sprawdzony i uznany na całym świecie model pozyskiwania kapitału. „Nie jest to krótkotrwały trend, a odpowiedź na realne potrzeby, uznana zarówno przez media, jak i profesjonalistów, którzy dostrzegają w nim wiele możliwości, także biznesowych. Choć jego historia jest dość krótka, to przedstawiany jest nie jako chwilowy trend, ale remedium na określone problemy i brak efektywności innych metod pozyskiwania kapitału, dostępnych na rynku" [Król, 2013, s. 64] Tego typu finansowanie nie jest jeszcze popularne w ekonomii społecznej. Być może w przyszłości to właśnie crowdfunding przyczyni się do stabilizacji PES na wolnym rynku. Świadczą o tym zarówno tempo rozwoju tej metody, jak i zainteresowanie Komisji Europejskiej, która w 2013 r. ogłosiła konsultacje pt. „Crowdfunding in the EU - Exploring the added value of potential EU action". Komentując to wydarzenie Filip Pazderski z Instytutu Spraw Publicznych zwrócił uwagę, że crowdfunding „mógłby służyć uzupełnieniu finansowania szczególnie najmniejszych przedsiębiorstw społecznych, umożliwiając im dodatkowe budowanie więzi z środowiskiem lokalnym, na rzecz którego pracują" [Pazderski, 2014].

Zupełnie inną formą dotacji jest sponsoring - ostatnie z czterech omawianych źródeł. Jest to mechanizm oparty na skojarzeniach - konsument widząc logo fundacji charytatywnej na bilbordzie dużej korporacji, przenosi pozytywne skojarzenia z fundacją na korporację. "Sponsoring oznacza odpłatne przysporzenie majątkowe wyrażające się w pieniądzach, rzeczach lub usługach, dokonywane przez firmę, osobę prywatną, instytucję itp. (sponsora) na rzecz osoby fizycznej, organizacji, instytucji itp. (sponsorowanego), w celu wykonania przez niego czynności określonych w umowie sponsoringu" [Sponsoring, 2015]. Pozytywny obraz sponsorowanego przenosi się na sponsora, co dla tego drugiego jest ważną formą promocji. Darowizna polega na przekazaniu danej kwoty na wybrany cel społeczny lub charytatywny bez oczekiwania czegokolwiek w zamian. Sponsoring to przekazanie danej kwoty w zamian za konkretne działania, zwykle o charakterze promocyjnym, opisane w umowie sponsorskiej. Dla firm sponsoring zapewnia większą widzialność w mediach, poszerzenie rynków zbytu, zwielokrotnienie zysku. Daje również możliwości kształtowania postaw konsumenckich. Do najczęściej sponsorowanych obszarów działalności pożytku publicznego należą: sport, kultura i sztuka, ekologia, sfera społeczna, ochrona zdrowia, oświata, nauka. W pozyskiwaniu sponsorów - podobnie jak darczyńców - ważna będzie opowieść o szczytnych celach, które pozyskane fundusze pomogą zrealizować. Dodatkowymi atutami będzie wszystko to, co zapewni sponsora o skuteczniejszej promocji, m.in. dobrze funkcjonująca, profesjonalna strona internetowa, materiały promocyjne, „wpadający w oko” logotyp, posiadanie misji i strategii oraz wspomniany już szczytny cel. Jednym z ciekawych narzędzi, które łączy aktywność społeczną ze sponsoringiem jest clik\&donate. To internetowe narzędzie bazujące na mechanizmie klikania (np. w brzuszek głodnego pajacyka). Klikają użytkownicy Internetu, a za każde takie kliknięcie związane z pojawieniem się reklamy płaci sponsor. Głównym zagrożeniem związanym ze sponsoringiem jest - podobnie jak w przypadku grantów - uzależnienie. Warto również pamiętać, że organizacja pozarzą- 
dowa sponsorowana przez inne podmioty staje się współodpowiedzialna za ich wizerunek. W przypadku PES, konieczne jest zadanie sobie pytań: czy chcemy naszą misję, realizację obranych celów, dzielić ze sponsorem oraz czy stać nas na sponsora, którego promocja może się okazać zbyt kosztowna w stosunku do przekazanej dotacji. Praktyka pokazuje jednak, że PES nie stronią od sponsorów. Dotyczy to zwłaszcza dużych, rozpoznawalnych na rynku organizacji. Pozyskiwanie sponsorów również nie musi być sprzeczne z gospodarczym charakterem PES, jeśli tylko będzie to działanie drugoplanowe. Sponsoring ma też ścisły związek ze społeczną odpowiedzialnością biznesu (CSR), co nie pozostaje bez znaczenia dla sektora ekonomii społecznej. „Współpraca przedsiębiorstw społecznych z firmami prywatnymi może - i powinna - być wielostronna. Jej fundamentem staje się coraz bardziej idea społecznej odpowiedzialności biznesu, rozumiana jednak nie przez perspektywę public relations, ale partnerstwa prywatno-społecznego, które ma służyć rozwojowi społeczno-gospodarczemu. (...) Praktyczne rozumienie i wdrożenie koncepcji społecznej odpowiedzialności biznesu może doprowadzić do wyjścia poza schemat doraźnego sponsoringu w kierunku zinstytucjonalizowanego formowania przez sieć przedsiębiorstw prywatnych zainteresowanych rozwijaniem działalności na danym terenie instrumentu finansowego (funduszu), który uruchamiałby kapitał finansowy na potrzeby przedsiębiorczości społecznej. Takie rozwiązanie otwierałoby w sposób znaczący przestrzeń innowacyjności w danej społeczności lokalnej, która wyzwolona i ukierunkowana z całą pewnością sprzyjałaby zwrotnie efektywności działalności gospodarczej zorientowanej na tę wspólnotę" [Hausner, Laurisz, Mazur, 2008, s. 14].

Korzystanie przez PES ze wszystkich czterech omówionych źródeł pozyskiwania funduszy jest gwarantem stabilizacji na rynku. Im mniej źródeł - tym mniejsze prawdopodo- bieństwo przetrwania organizacji. Dlatego, jeszcze przez założeniem PES, warto pomyśleć o konieczności zatrudnienia fundraisera. Nie wystarczą tylko szczytne cele społeczne, potrzebne są też środki, które umożliwią ich realizację. Taki wniosek podziela Jerzy Mika: „Głównym zadaniem działalności każdej organizacji jest jej utrzymanie. Podstawowe pytanie o źródła przychodów, a w efekcie o finansowanie działalności przy zakładaniu organizacji nie są jednak najważniejsze. Podejście »jakoś to będzie« stopniowo się zmienia, ale wciąż zbyt wolno" [Mika, 2015, s. 85]. „Bezpieczeństwo finansowe organizacji może zapewnić zróżnicowanie źródeł dochodów" [ibidem, s. 89]. Ten sam wniosek jest też wynikiem własnych obserwacji autora niniejszego tekstu.

\section{Podsumowanie}

Podsumowując powyższe wywody dobrze jest zastanowić się nad tymi elementami ekonomii społecznej, które w szczególności istotne są dla skutecznego fundraisingu. Największym sekretem fundraisingu jest, wg Roberta Kawałko, proszenie zawsze, kiedy się tego potrzebuje [SiePomaga]. Ekonomia społeczna to specyficzna forma proszenia. PES nie tylko proszą o wsparcie, ale przede wszystkim same tę pomoc wypracowują przez działalność gospodarczą. Szukanie sponsorów, próby zdobycia dotacji w konkursach grantowych czy pozyskiwanie indywidualnych darczyńców powinny być tylko dodatkami do prowadzonej z pomysłem działalności gospodarczej. Fundraising stwarza istotną szansę właśnie na takie dodatkowe środki finansowe. W kwestii pozyskiwania funduszy jest to kluczowa różnica pomiędzy PES a pozostałymi podmiotami trzeciego sektora, dla których działalność gospodarcza to tylko jedna z możliwości pozyskiwania funduszy.

Innym aspektem wyróżniającym PES z szeregu organizacji pozarządowych jest szcze- 
gólny, szczytny cel społeczny. Dlatego o tym celu należy mówić z pasją. Takie cele posiadają też inne podmioty trzeciego sektora, takie cele nie są też obce sektorowi gospodarczemu, zwłaszcza w nurcie CSR. Jednak cele PES mają swój wspólny mianownik, którym jest przeciwdziałanie wykluczeniu społecznemu. Są definiowane na gruncie marzeń i pasji, ale także potrzeby samowystarczalności i funkcjonowania w społeczeństwie. Cele poszczególnych PES osadzone są w konkretnej historii. Właśnie ta niepowtarzalna, oryginalna historia jest skutecznym narzędziem w rękach fundraisera. Techniką, która pomaga wykorzystać to narzędzie jest test windy. Jest to technika krótkich, a zarazem przekonujących prezentacji. Jej nazwa wzięła się z angielskiego elevator pitch (wykład w windzie). Fundraiserzy uczą się mówić o celu organizacji w kilkuminutowych wypowiedziach - tak jakby niespodziewanie spotkali potencjalnego darczyńcę czy sponsora w windzie, mając na prezentację czas przejazdu na najwyższe piętro biurowca. Aby ułatwić taką wypowiedź zadaje się 6 konkretnych pytań: (1) Kim jesteśmy? Jaka jest misja naszej organizacji? (2) Co oferujemy? Co robimy dla innych? (3) W jakim obszarze działamy? Jakie są potrzeby w tym obszarze? (4) Kto jest naszym beneficjentem? Dla kogo działamy? Komu pomagamy? (5) W jaki sposób możesz nam pomóc? (6) Jakie odniesiesz korzyści ze współpracy z nami? [Instytut Fundraisingu c]. Tego typu ćwiczenie powinno być wykonywane nie tylko przez fundraiserów, ale także przez członków zarządu, pozwala bowiem na utożsamienie się z celami organizacji. Przy okazji testu windy warto się też zastanowić, czy misja organizacji jest rozumiana i popierana przez społeczeństwo. „W układzie społecznym fundraising ma sens tylko wtedy, jeśli znajdzie się ktoś, kto zechce pomóc komuś innemu" [Grzegorczyk, 2011, s. 135]. Szansą dla PES jest misja, która zainte- resuje społeczeństwo. Zagrożeniem jest działalność, która nie znajdzie zrozumienia w opinii publicznej.

Skuteczność fundraisingu w PES może być większa również dzięki wspólnotowemu charakterowi działania (jedno z przytaczanych już kryteriów społecznych PES). Badania trzeciego sektora wskazują na odsetek zaangażowanych w działalność organizacji członków. "Z deklaracji organizacji wynika, że w życie stowarzyszeń aktywnie włącza się około połowa członków, reszta pozostaje bierna i faktycznie nie uczestniczy w ich działaniach" [Kondycja sektora, 2015, s. 11]. W PES motywacja do aktywności jest większa. Chodzi bowiem o przeciwdziałanie wykluczeniu społecznemu nie w imieniu organizacji czy beneficjentów, ale we własnym. Brakuje badań, które udokumentowałyby takie wnioskowanie. Jednak biorąc pod uwagę charakterystykę PES, każdy z członków takiej organizacji jest zainteresowany jej sukcesem na rynku.

Podmioty ekonomii społecznej mają zbyt wiele do stracenia, aby pozwolić sobie na nieefektywne pozyskiwanie funduszy. Cele tego typu organizacji dotyczą grup defaworyzowanych, wykluczonych bądź zagrożonych wykluczeniem. To konkretni ludzie, którzy z pomocą innych próbują wziąć swój los w swoje ręce. Porażka spowodowana brakiem funduszy na działalność będzie nie tylko niepowodzeniem organizacji, ale także tych pojedynczych ludzi, którzy uwierzyli, że im się uda. W tym kontekście myślenie fundraisingowe od samego początku powinno kształtować organizacje funkcjonujące w obszarze ekonomii społecznej. Nie mogą to być okazjonalnie zdobyte granty czy pojedyncze wpłaty od darczyńców. Nie może to też być sama działalność gospodarcza. Ważne jest, aby był to fundraising w pełni profesjonalny, bo tylko taki będzie skuteczny i w perspektywie czasu pozwoli osiągać zarówno założone cele społeczne, jak i ekonomiczne. 


\section{Literatura}

Bajguza A. (2012). „Grantoza, czyli jak się marnotrawi dotację", Radio Białystok, http://www.radio.bialystok. pl/wiadomosci/index/id/76128 (dostęp 28.06.2016).

Bakalarz M. (red.) (2009). Działalność gospodarcza w organizacjach pozarządowych. Warszawa: Fundacja Jesteśmy Aktywni.

Cibor K. (2015). Jak finansować współpracę. Warszawa: Fundacja Inicjatyw Społeczno-Ekonomicznych.

DESiPP. Podstawowe pojęcia, Departament Ekonomii Społecznej i Pożytku Publicznego, http://www.pozytek.gov.pl/Podstawowe,pojecia,380.html (dostęp 14.11.2016).

Frączak P. (2006). "Szkic do historii ekonomii społecznej w Polsce", Ekonomia Społeczna. Teksty, Fundacja Inicjatyw Społeczno Ekonomicznych.

FISE. Co to jest ekonomia społeczna? Fundacja Inicjatyw Społeczno-Ekonomicznych, http://www.ekonomiaspoleczna.pl/x/433225 (dostęp 14.11.2016).

Giza-Poleszczuk A., Hausner J. (red.) (2008). Ekonomia społeczna w Polsce: osiagnięcia, bariery rozwoju i potencjał w świetle wyników badań. Warszawa: Fundacja Inicjatyw Społeczno-Ekonomicznych.

Głowacki J. (2008). "Metody i procedury pozyskiwania środków finansowych przez organizacje społeczne", w: D. Kwiecińska, A. Pacut (red.), Budowanie kompetencji dla przedsiębiorczości społecznej. Sylabusy do szkoleń. Kraków: Uniwersytet Ekonomiczny w Krakowie.

Głowacki J., Sułkowski R. (2012). „Jak finansować ekonomię społeczną?", w: M. Frączek, M. Pokora (red.), Ekonomia społeczna w Małopolsce. Kraków: Fundacja Gospodarki i Administracji Publicznej.

Grzegorczyk A. (2009). Fundraising w działalności organizacji pozarzadowych - raport badawczy. Warszawa: Wyższa Szkoła Promocji.

Grzegorczyk A. (red.) (2011). Fundraising w działalności organizacji pozarządowych. Warszawa: Wyższa Szkoła Promocji.

Hausner J. (2008). "Czy finansowanie ze środków publicznych psuje przedsiębiorczość społeczną?", Ekonomia Społeczna, nr 1.

Hausner J. (red) (2008). Finansowanie i otoczenie prawne podmiotów ekonomii społecznej. Kraków: Uniwersytet Ekonomiczny w Krakowie.

Hausner J., Laurisz N., Mazur S. (2008). „Przedsiębiorstwo społeczne - konceptualizacja", w: Hausner J. (red.), Zarządzanie podmiotami ekonomii społecznej. Kraków: Uniwersytet Ekonomiczny w Krakowie.

Herbst I. (2008). Analiza możliwości finansowania podmiotów ekonomii społecznej w Polsce. Warszawa: Bank DnB NORD Polska SA.

Herbst I. (2012). „Finansowanie podmiotów ekonomii społecznej w Polsce", Ekonomia Społeczna, nr 1.

Instytut Fundraisingu a. Mini słownik fundraisingu, http://www.instytutfundraisingu.pl/mini-slownik-fundraisingu/grants.html, (dostęp 28.06.2016).
Instytut Fundraisingu b. O fundraisingu, http:// www.instytutfundraisingu.pl/fundraising/o-fundraisingu.html (dostęp 28.06.2016).

Instytut Fundraisingu c. Technika testu windy - jak wykorzystać ja w fundraisingu? http://www.instytutfundraisingu.pl/e-booki-i-artykuly-o-fundraisingu/ technika-testu-windy-\%E2\%80\%93-jak-wykorzystacja-w-organizacji-pozarzadowej.html (dostęp 28.06.2016).

Karwińska A., Sułkowska W. (2008). „Kontrowersje wokół finansowania przedsiębiorczości społecznej", Ekonomia Społeczna, nr 2.

Król K. (2013). Crowdfunding, od pomysłu do biznesu, dzięki społeczności. Warszawa: Wydawnictwo Crowdfunding.pl.

Królikowska A. (2008). „Podstawowe zasady finansowania podmiotów ekonomii społecznej", w: J. Hausner (red.), Finansowanie i otoczenie prawne podmiotów ekonomii społecznej. Kraków: Uniwersytet Ekonomiczny w Krakowie.

Lewandowska K. (2015). "Nie taki grant straszny”, NCK, http://nck.pl/blog-kultura-sie-liczy/316936-nietaki-grant-straszny/\#more-6323 (dostęp 28.06.2016).

Mazur S., Pacut A. (2008). „Publiczne i publiczno-prywatne źródła finansowania przedsiębiorstw społecznych, projektów społecznych i zatrudnienia z funduszy strukturalnych", w: J. Hausner (red.), Wspieranie ekonomii społecznej. Kraków: Uniwersytet Ekonomiczny w Krakowie.

Mazurczak M, Łukasiak P. (2002). Jak przygotować plan zbierania funduszy. Mały poradnik dla fundacji i stowarzyszeń. Warszawa: Akademia Rozwoju Filantropii.

MliR (2015). Polityka Spójności 2014-2020, Informacja prasowa z 26 lutego 2015 roku, https://www. funduszeeuropejskie.gov.pl/media/1335/Informacja_prasowa_perspektywa2014_2020.pdf, (dostęp 28.06.2016).

Mika J. (2015). „Fundraising, czyli narzędzia dobrych relacji w ekonomii społecznej", w: M. Majchrzak (red.), Finanse ekonomii społecznej, tom 1. Szczecin-Poznań: Akademia Lidera WSB w Poznaniu.

Mika J. (red.) (2014). Fundraising. Teoria i praktyka. Kraków: Polskie Stowarzyszenie Fundrisingu.

Pazderski F. (2014). Kolektywne inwestowanie społeczne, Ekonomiaspoleczna.pl, 18.12.2013, http:// www.ekonomiaspoleczna.pl/wiadomosc/949609. html (dostęp 28.06.2016).

Pełka W. (2012). „Rynkowe instrumenty finansowania działalności przedsiębiorstw społecznych w Polsce", Ekonomia Społeczna, nr 2.

Płonka M. (2008). „Dylematy finansowania podmiotów ekonomii społecznej", Ekonomia Społeczna, nr 1.

Polskie Stowarzyszenie Fundraisingu. O fundraisingu, http://www.fundraising.org.pl/o-fundraisingu/ (dostęp 28.06.2016).

PWN. Słownik języka polskiego, http://sjp.pwn.pl/sjp/ kultywowac;2565210.html (dostęp 28.06.2016). 
Setniewska D. (2015). Informacje o wynikach 1\%, NGO.PL, http://portal.ngo.pl/wiadomosc/1670310. html (dostęp 28.06.2016).

SiePomaga (2012). Trudna dola fundraisera, http:// blog.siepomaga.pl/2012/05/trudna-dola-fundraisera/ (dostęp: 28.06.2016).

Sobolewski A., Klimek P., Piekutowski J. (red.) (2009). Zewnętrzne finansowanie podmiotów ekonomii społecznej. Szczecin: Zachodniopomorska Biblioteka Ekonomii Społecznej.

Socha R. (2011). „Jak się marnuje dotacje”, Polityka.pl, 1 grudnia, http://www.polityka.pl/tygodnikpolityka /10l/1521424,1,jak-sie-marnuje-dotacje.read (dostęp: 28.06.2016).
Sponsoring (2015). „Wszystkie najważniejsze informacje o sponsoringu", NGO.PL, http://poradnik.ngo. pl/sponsoring (dostęp 28.06.2016).

Szymańska A., Jegers M. (2014). „The Structure of Capital and Revenue in Social Enterprises", Ekonomia Społeczna, nr 1.

Świecka B. (2015). „Finansowanie zwrotne podmiotów ekonomii społecznej", w: M. Majchrzak (red.), Finanse ekonomii społecznej, tom 1. Szczecin-Poznań: Akademia Lidera WSB w Poznaniu.

Tokarz B. (red.) (2005). Fundraising to sztuka, której można się nauczyć. Warszawa: Akademia Rozwoju Filantropii.

Wygnański J. (2008). „Ekonomizacja sektora pozarządowego", Ekonomia Społeczna, nr 1.

\section{Fundraising in the context of social economy entities}

Summary: Fundraising is planned, ethical and efficient money-raising activity, which is supposed to serve to common good. Social economy constitutes such a common good. So it is important to think about financing of these activities. The aim of article is to present the fundraising in the context of social economy. Author characterizes polish fundraising within historical context and taking into account its recent development. Following parts of the article describe methods of raising money, especially the principles, ethical consideration and four main sources of money. The author - academic teacher and certified fundraiser - describes process of raising money, based on his own experiences and contents of books and websites on fundraising.

Fundraising is a base for development and effectiveness of the social economy. It is very important to use all of four described sources of money. This guarantees stability. It is beneficial to think about employing a fundraiser. Social enterprises have too much to lose. So they cannot afford non effective fundraising. That is why the issues described in this article need serious consideration in practice of social economy.

Keywords: fundraising, social economy, third sector, The Polish Fundraising Association.

\section{Prawa autorskie i licencja / Copyright and License}

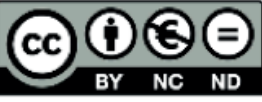

Artykuł opublikowano na licencji Creative Commons

Uznanie autorstwa - Użycie niekomercyjne - Bez utworów zależnych 3.0 Polska

http://creativecommons.org/licenses/by-nc-nd/3.0/pl/

This article is published under the terms of the Creative Commons Attribution - NonCommercial - NoDerivs (CC BY-NC-ND 3.0) License

http://creativecommons.org/licenses/by-nc-nd/3.0/ 